\title{
Physiologic Hyperinsulinemia Stimulates Protein Synthesis and Enhances Transport of Selected Amino Acids in Human Skeletal Muscle
}

\author{
Gianni Biolo, ${ }^{\star 1}$ R. Y. Declan Fleming, ${ }^{\star}$ and Robert R. Wolfe ${ }^{\mathbf{5 1}}$ \\ Departments of *Internal Medicine, ${ }^{\ddagger}$ Surgery, and ${ }^{8}$ Anesthesiology, The University of Texas Medical Branch; and the ${ }^{\top}$ Shriners Burns \\ Institute, Galveston, Texas 77550
}

\begin{abstract}
We have investigated the mechanisms of the anabolic effect of insulin on muscle protein metabolism in healthy volunteers, using stable isotopic tracers of amino acids. Calculations of muscle protein synthesis, breakdown, and amino acid transport were based on data obtained with the leg arteriovenous catheterization and muscle biopsy. Insulin was infused $(0.15 \mathrm{mU} / \mathrm{min}$ per $100 \mathrm{ml} \mathrm{leg})$ into the femoral artery to increase femoral venous insulin concentration (from $10 \pm 2$ to $77 \pm 9 \mu \mathrm{U} / \mathrm{ml}$ ) with minimal systemic perturbations. Tissue concentrations of free essential amino acids decreased $(P<0.05)$ after insulin. The fractional synthesis rate of muscle protein (precursor-product approach) increased $(P<0.01)$ after insulin from $0.0401 \pm 0.0072$ to $0.0677 \pm 0.0101 \% / h$. Consistent with this observation, rates of utilization for protein synthesis of intracellular phenylalanine and lysine (arteriovenous balance approach) also increased from $40 \pm 8$ to $59 \pm 8(P<0.05)$ and from $219 \pm 21$ to $298 \pm 37(P<0.08) \mathrm{nmol} / \mathrm{min}$ per $100 \mathrm{ml}$ leg, respectively. Release from protein breakdown of phenylalanine, leucine, and lysine was not significantly modified by insulin. Local hyperinsulinemia increased $(P<0.05)$ the rates of inward transport of leucine, lysine, and alanine, from $164 \pm 22$ to $200 \pm 25$, from $126 \pm 11$ to $221 \pm 30$, and from $403 \pm 64$ to $595 \pm 106 \mathrm{nmol} / \mathrm{min}$ per $100 \mathrm{ml}$ leg, respectively. Transport of phenylalanine did not change significantly. We conclude that insulin promoted muscle anabolism, primarily by stimulating protein synthesis independently of any effect on transmembrane transport. (J. Clin. Invest. 1995. 95:811819.) Key words: insulin - fractional synthesis rate • protein breakdown • arteriovenous catheterization • skeletal muscle
\end{abstract}

\section{Introduction}

There is considerable evidence that insulin plays a major role in the regulation of muscle protein metabolism, but its mechanisms of action are not fully understood $(1,2)$. An anabolic

This work was presented in abstract form at the 53rd annual meeting of the American Diabetes Association, Las Vegas, NV 12-15 June, 1993.

Address correspondence to Robert R. Wolfe, Shriners Burns Institute, 815 Market Street, Galveston, TX 77550. Phone: 409-770-6605; FAX: 409-770-6825.

Received for publication 26 April 1994 and in revised form 7 October 1994.

J. Clin. Invest.

(c) The American Society for Clinical Investigation, Inc.

0021-9738/95/02/0811/09 $\$ 2.00$

Volume 95, February 1995, 811-819 hormone can potentially exert its effect by increasing protein synthesis and/or inhibiting proteolysis. An insulin stimulatory effect on muscle protein synthesis has been clearly shown in different experimental conditions $(1-10)$. Insulin also decreases the proteolytic activity of lysosomes (11), but recent evidence suggests that the bulk of muscle protein is degraded by a different pathway that is not under insulin control (1214). Further, the processes of synthesis and breakdown can be directly affected by the rates of transmembrane transport of amino acids which, in turn, could be under hormonal control. Insulin has been shown to influence the activity of at least four distinct transport systems of amino acids, named systems A, ASC, $N^{m}$, and $x_{c}{ }^{-}(16-21)$. However, evidence indicates that the insulin effects on amino acid transport are minor for most of the system studied $(19,21)$, except possibly for system $\mathrm{N}^{\mathrm{m}}(18)$.

Despite the evidence that insulin may affect all possible steps of muscle protein metabolism, the demonstration of such effects in vivo in humans has been difficult for both physiological and technical reasons. When insulin was infused, systemically hypoaminoacidemia developed $(22,23)$ because of the hormone action on extramuscular tissues (24). As a consequence, the availability of plasma amino acids decreased, counteracting the anabolic insulin effect on muscle $(24,25)$. Furthermore, the rates of muscle protein synthesis and breakdown have been measured in human limbs (leg or forearm) as rates of amino acid appearance into and disappearance from plasma $(26,27)$. This approach underestimates the actual intracellular values of protein synthesis and breakdown, because a fraction of the intracellular amino acids resulting from protein breakdown is directly reincorporated into protein without entering plasma. The extent of such underestimation depends on the isotopic equilibration between extracellular and intracellular free amino acid pools, which is primarily determined by the transmembrane transport kinetics of each individual amino acid $(28,29)$.

In this study we have evaluated the insulin effects on amino acid and protein metabolism in the human skeletal muscle using a new method $(28,29)$, that combines the traditional arterialvenous balance technique with the biopsy of the vastus lateralis muscle. Intracellular amino acid and protein kinetics were directly assessed, whereas transmembrane amino acid transport was separately determined as the rate of amino acid exchange between the intracellular and vascular compartments. To assess the validity of the model-derived values of muscle protein synthesis (and those other model-derived values based on the same assumptions), we have also used the traditional precursor-product technique (30). Insulin was directly infused into the femoral artery to raise femoral venous insulin concentration to a high physiological level, without decreasing amino acid delivery to the leg.

\section{Methods}

Subjects. Six healthy male volunteers were studied in the postabsorptive state. The mean \pm SEM age was $29 \pm 5$, the body wt was $73 \pm 5 \mathrm{~kg}$, the 
height was $170 \pm 3$, and the body mass index was $25 \pm 1 \mathrm{~kg} / \mathrm{cm}^{2}$. The leg volume, estimated using an anthropometric approach (31), was $10,327 \pm 657 \mathrm{ml}$. All subjects gave informed, written consent before participating in the study, which was approved by the Institutional Review Board of The University of Texas Medical Branch at Galveston, Texas.

Isotopes. L- $\left[1-{ }^{13} \mathrm{C}\right]$ leucine (99\% enriched), L-[ring $\left.-{ }^{13} \mathrm{C}_{6}\right]$ phenylalanine (99\% enriched), and $\mathrm{L}-\left[2,3,3,3-{ }^{2} \mathrm{H}_{4}\right]$ alanine (98\% enriched) were purchased from Cambridge Isotope Laboratories, Inc. (Woburn, MA); L- $\left[1,2-{ }^{13} \mathrm{C}_{2}\right]$ leucine (99\% enriched), L- $\left[2-{ }^{15} \mathrm{~N}\right]$ lysine (99\% enriched), $\quad \mathrm{L}-\left[1,2-{ }^{13} \mathrm{C}_{2}, 6,6-{ }^{2} \mathrm{H}_{2}\right]$ lysine (98\% enriched), $\quad \mathrm{L}-\left[2-{ }^{15} \mathrm{~N}\right]-$ phenylalanine (99\% enriched), and L-[ ring- $\left.{ }^{2} \mathrm{H}_{5}\right]$ phenylalanine $(98 \%$ enriched) were purchased from Tracer Technologies, Inc. (Somerville, MA). $\mathrm{L}\left[1-{ }^{13} \mathrm{C}\right]$ alanine ( $99 \%$ enriched) was purchased from Isotec, Inc. (Miamisburg, $\mathrm{OH}$ ).

Experimental protocol. The subjects were admitted to the Clinical Research Center of The University of Texas Medical Branch at Galveston in the morning of the study at 6:00 a.m., after an overnight fast. An 18-gauge polyethylene catheter was inserted into the left antecubital vein for infusion of labeled amino acids. Using flexible guide wires, two 8-cm length polyethylene catheters (Cook Inc., Bloomington, IN) were inserted into the right femoral artery and vein for blood sampling. The femoral arterial catheter was also used for continuous infusion of insulin and primed-continuous infusion of indocyanine green (Becton Dickinson Microbiology Systems, Cockeysville, MA). Systemic concentrations of insulin and indocyanine green were measured in the right arterialized wrist vein that was cannulated with a 20 -gauge polyethylene catheter and maintained at $\sim 65^{\circ} \mathrm{C}$. Catheters were inserted using lidocaine. Patency of catheters was maintained by saline infusion.

After obtaining a blood sample for measurement of background amino acid enrichment and indocyanine green concentration, the infusion protocol was initiated. First, a primed-continuous infusion of $L-$ [ ring- ${ }^{13} \mathrm{C}_{6}$ ]phenylalanine was started, followed at $60 \mathrm{~min}$ by $\mathrm{L}-\left[1-{ }^{13} \mathrm{C}\right]-$ leucine, $\mathrm{L}-\left[2-{ }^{15} \mathrm{~N}\right]$ lysine, and $\mathrm{L}-\left[1-{ }^{13} \mathrm{C}\right]$ alanine. In four subjects a primed-continuous infusion of $\mathrm{L}-\left[2-{ }^{15} \mathrm{~N}\right]$ phenylalanine was also performed to exclude the possibility of isotopic discrimination of the L[ring- ${ }^{13} \mathrm{C}_{6}$ ] phenylalanine. Tracer infusions were maintained throughout the experiment. The following tracer infusion rates (IR) ${ }^{1}$ and priming doses (PD) have been used: $\mathrm{L}-\left[\right.$ ring- $\left.{ }^{13} \mathrm{C}_{6}\right]$ phenylalanine (and L- [2$\left.{ }^{15} \mathrm{~N}\right]$ phenylalanine ): $\mathrm{IR}=0.05 \mu \mathrm{mol} / \mathrm{kg}$ per $\mathrm{min}, \mathrm{PD}=2 \mu \mathrm{mol} / \mathrm{kg}$; L- $\left[1-{ }^{13} \mathrm{C}\right.$ ]leucine: $\mathrm{IR}=0.08 \mu \mathrm{mol} / \mathrm{kg}$ per $\mathrm{min}, \mathrm{PD}=4.8 \mu \mathrm{mol} / \mathrm{kg}$; $\mathrm{L}-[2-$ $\left.{ }^{15} \mathrm{~N}\right]$ lysine: $\mathrm{IR}=0.08 \mu \mathrm{mol} / \mathrm{kg}$ per $\mathrm{min}, \mathrm{PD}=7.2 \mu \mathrm{mol} / \mathrm{kg} ; \mathrm{L}\left[1-{ }^{13} \mathrm{C}\right]-$ alanine: $\mathrm{IR}=0.35 \mu \mathrm{mol} / \mathrm{kg}$ per $\mathrm{min}, \mathrm{PD}=35 \mu \mathrm{mol} / \mathrm{kg}$. This experimental protocol was designed to simultaneously assess in skeletal muscle the kinetics of intracellular-free amino acids and the fractional synthetic rate (FSR) of protein by the incorporation of L-[ring- $\left.{ }^{13} \mathrm{C}_{6}\right]-$ phenylalanine (29). Isotopic steady state in the free amino acid pools in blood and muscle was required to calculate intracellular amino acid kinetics at the end of the basal and insulin periods, i.e., between 180 and $240 \mathrm{~min}$, and between 360 and $420 \mathrm{~min}$. Measurement of FSR by the incorporation of $\mathrm{L}-\left[\right.$ ring- $\left.{ }^{13} \mathrm{C}_{6}\right]$ phenylalanine required steady state enrichment of the precursor during the incorporation period, i.e., between 60 and $240 \mathrm{~min}$, and between 240 and $420 \mathrm{~min}$.

At $60 \mathrm{~min}$ the first muscle biopsy was taken to measure isotopic carbon enrichment of bound and free phenylalanine in muscle. The biopsy was taken from the lateral portion of the right vastus lateralis muscle, $\sim 20 \mathrm{~cm}$ above the knee, using a 4-mm Bergström biopsy needle (Stille, Stockholm, Sweden) (32). Approximately $30-50 \mathrm{mg}$ of

1. Abbreviations used in this paper: $F_{\text {in }}$, amino acid flow into the leg from systemic circulation via femoral artery; $F_{M, A}$, inward amino acid transport from femoral artery into free muscle amino acid pool; $F_{M, 0}$, intracellular amino acid appearance; $F_{0, M}$, intracellular amino acid utilization; $F_{\text {out }}$, amino acid flow from the leg via femoral vein; FSR, fractional synthetic rate; $F_{\mathrm{V}, \mathrm{M}}$, outward amino acid transport from intracellular pool into femoral vein; IR, infusion rate; PD, priming dose; Ra, rate of amino acid appearance in plasma. muscle tissue was obtained with each biopsy. This procedure yields a sample of mixed skeletal muscle. Blood and visible fat and connective tissue were quickly removed from the specimen, and the tissue was immediately frozen in liquid nitrogen and stored at $-80^{\circ} \mathrm{C}$ for later analysis.

To measure leg blood flow in the basal state, at $165 \mathrm{~min}$ a primedcontinuous infusion of indocyanine green dye (IR $=0.5 \mathrm{mg} / \mathrm{min} ; \mathrm{PD}=5$ $\mathrm{mg}$ ) was started into the femoral artery and maintained until $240 \mathrm{~min}$ $(33,34)$. Between 180 and 240 min blood samples were taken every $20 \mathrm{~min}$ from the femoral vein, an arterialized wrist vein, and the femoral artery. To allow sampling from the femoral artery, the dye infusion was stopped for $<10 \mathrm{~s}$ and then quickly resumed. Arterial samples were always taken after samples from the femoral and wrist veins to avoid interference with blood flow measurement. At $240 \mathrm{~min}$ (end of basal period) the second muscle biopsy was taken. After the basal period, insulin was infused directly into the femoral artery at $0.15 \mathrm{mU} / \mathrm{min}$ per $100 \mathrm{ml}$ leg for $3 \mathrm{~h}$. Blood glucose was maintained at the basal euglycemic levels by means of appropriate $5 \%$ dextrose infusion. Between 360 and 420 min the measurement of leg blood flow was repeated and blood samples were taken as described for the basal period. At $420 \mathrm{~min}$, before stopping tracer and insulin infusions, the third muscle biopsy was taken from the vastus lateralis muscle of the right leg.

Analysis. Blood samples from the femoral artery and vein for determination of amino acid enrichment and concentration were immediately precipitated in preweighed tubes containing $15 \%$ sulfosalicylic acid. Simultaneously, a known amount of an internal standard mixture (100 $\mu \mathrm{l} / \mathrm{ml}$ blood) was added to the tube and thoroughly mixed. The composition of the internal standard solution was the following: $22.8 \mu \mathrm{mol} / \mathrm{liter}$ of $\mathrm{L}$-[ring- $\left.{ }^{2} \mathrm{H}_{5}\right]$ phenylalanine, $13.6 \mu \mathrm{mol} /$ liter of $\mathrm{L}-\left[1,2-{ }^{13} \mathrm{C}_{2}\right]$ leucine, $110.7 \mu \mathrm{mol} /$ liter of $\mathrm{L}-\left[1,2-{ }^{13} \mathrm{C}_{2}, 6,6-{ }^{2} \mathrm{H}_{2}\right]$ lysine, and $224.3 \mu \mathrm{mol} / \mathrm{liter}$ of $\mathrm{L}-\left[2,3,3,3-{ }^{2} \mathrm{H}_{4}\right]$ alanine. The tubes were weighed again and the difference was recorded as blood volume after subtraction of the internal standard volume. The sulfosalicylic extract was frozen for later analysis. To determine the enrichment of the infused tracers and of the internal standards of free phenylalanine, leucine, lysine, and alanine in the whole blood, the nitrogen-acetyl- $n$-propyl esters were prepared as described in earlier studies $(28,29,35)$. Blood samples from the femoral and arterialized wrist veins were collected to measure indocyanine green concentration in serum, as described (34). Leg plasma flow was calculated from steady state values of dye concentration in the femoral and arterialized wrist veins as referenced (34). Leg blood flow was calculated from the hematocrit. Insulin concentration in plasma was measured by double-antibody radioimmunoassay. Plasma glucose concentration was determined by the glucose oxidase method using a glucose analyzer (Beckman Instruments, Inc., Brea, CA).

Each tissue sample was weighed and muscle protein was precipitated with $0.5 \mathrm{ml}$ of $10 \%$ trichloroacetic acid. An internal standard solution was then added $(0.7 \mu \mathrm{l} / \mathrm{mg}$ tissue $)$ and thoroughly mixed. The composition of the internal standard solution used for tissue samples was the following: $22.8 \mu \mathrm{mol} /$ liter of $\mathrm{L}-\left[\right.$ ring- ${ }^{2} \mathrm{H}_{5}$ ] phenylalanine, $13.6 \mu \mathrm{mol} /$ liter of $\mathrm{L}-\left[1,2-{ }^{13} \mathrm{C}_{2}\right]$ leucine, $110.7 \mu \mathrm{mol} /$ liter of $\mathrm{L}-\left[1,2-{ }^{13} \mathrm{C}_{2}, 6,6-{ }^{2} \mathrm{H}_{2}\right]-$ lysine, and $224.3 \mu \mathrm{mol} /$ liter of $\mathrm{L}-\left[2,3,3,3-{ }^{2} \mathrm{H}_{4}\right]$ alanine. The tissue was then homogenized, centrifuged, and the supernatant collected. This procedure was repeated twice more. Then, the pooled supernatant $(\sim 1.5$ $\mathrm{ml}$ ) was processed separately to produce the nitrogen-acetyl- $n$-propyl derivatives of intracellular amino acids $(29,35)$. The pellet was washed once with water and three times with absolute ethanol, and placed overnight in $80^{\circ} \mathrm{C}$ oven to evaporate the ethanol. Total water content in muscle was obtained from the difference between weights of wet and dried sample. Lipid content was found negligible. The weight of the dried pellet was recorded as muscle protein weight. The precipitated proteins were then hydrolyzed at $110^{\circ} \mathrm{C}$ for $36 \mathrm{~h}$ with $6 \mathrm{~N}$ constant boiling $\mathrm{HCl}$. The protein hydrolysate was then passed through columns of acid-washed celite to remove carbon particles. The purified amino acids were dried under vacuum using a Speed-Vac (Savant Instruments, Inc., Farmingdale, NY). Each sample was reconstituted in $150 \mu 10.2 \mathrm{M}$ sodium phosphate buffer ( $\mathrm{pH} 3.2$ ). A modification (29) of the method previously used for leucine (36) was used to isolate phenylalanine by 
HPLC (LKB Instruments Inc., Bromma, Sweden). A small amount of $\mathrm{L}\left[1-{ }^{14} \mathrm{C}\right]$ phenylalanine was added to the sample to identify the phenylalanine fraction because conventional detection (i.e., fluorometric detector) requires derivatization, which would add other carbons that would also contribute to the $\mathrm{CO}_{2}$ after combustion. For the same reason, a carbon-free buffer system was required. Purity of the phenylalanine fraction was verified using a different HPLC system with fluorometric detector (LKB Instruments Inc.). The phenylalanine peak was well separated from other amino acids, i.e., tyrosine. Furthermore, the tyrosine peak was always $<2 \%$ of the phenylalanine peak. The ability to isolate pure phenylalanine was an advantage compared to using leucine as the tracer, because complete separation of leucine and isoleucine can be a problem. The samples containing pure phenylalanine were dried under nitrogen and placed in tin containers and combusted using a carbon/nitrogen analyzer (Nitrogen Analyzer 1500; Carlo Erba Instruments/Fisons, Serono, Italy). The resulting $\mathrm{CO}_{2}$ gas was automatically injected into an isotope-ratio mass-spectrometer (VG Isogas; VG Instruments/Fisons Instruments, Middlewich, United Kingdom) for determination of the ${ }^{13} \mathrm{C} /{ }^{12} \mathrm{C}$ isotope ratio in protein-bound phenylalanine.

We have evaluated the possibility of contamination of the muscle protein precipitate by trapped free labeled phenylalanine. Radiolabeled L- $\left[\mathrm{U}-{ }^{14} \mathrm{C}\right]$ phenylalanine (Sigma Chemical Co., St. Louis, MO) dissolved in $0.9 \%$ saline was added to three muscle-biopsy samples obtained in normal volunteers. The samples were then deproteinized, homogenized, and washed as described above (i.e., three times with $10 \%$ trichloroacetic acid, one time with water, and three times with absolute ethanol). The radioactivity was measured in the supernatant obtained in the progressive washes using a liquid scintillation counter (LKB Wallac, Gaithersburg, MD). The total amount of radioactivity added to each sample was recovered in the first three washes, whereas in the fluid obtained from the further four washed, no radioactivity above the background was detected. These results indicate that the purified muscle protein was not contaminated by any free-labeled phenylalanine.

The isotopic enrichment of free amino acids in blood and muscle samples were determined by gas-chromatography mass-spectrometry (Model 5985; Hewlett-Packard Co., Palo Alto, CA) by chemical ionization and selected ion monitoring $(28,29,35)$. Data were expressed as tracer/tracee ratio, with correction for the contribution of isotopomers of small weight to the apparent enrichment of isotopomers with a greater mass $(28,29,35)$. Enrichment of $\mathrm{L}\left[\right.$ ring $\left.-{ }^{13} \mathrm{C}_{6}\right]$ phenylalanine was further corrected using a factor of 0.93 to account for an overestimation of enrichment, due to the different isotopomer distribution of the tracer and the naturally occurring phenylalanine $(29,35)$.

Concentrations (C) $(\mathrm{nmol} / \mathrm{ml})$ of free amino acids in blood and total muscle water was calculated as follows $(28,29,35)$ :

$\mathrm{C}=\mathrm{Q}_{\mathrm{IS}} /\left(\mathrm{V} \cdot \mathrm{E}_{\mathrm{IS}}\right)$

where $\mathrm{Q}_{\text {Is }}$ ( $\mathrm{nmol}$ ) is the amount of internal standard added to the sample, $\mathrm{V}$ is the volume of blood or muscle water, and $E_{1 S}$ is the internal standard tracer/tracee ratio in blood or muscle water as measured by gas-chromatography mass-spectrometry. Measured values of enrichment and concentrations relative to total tissue water were corrected according to references 29 and 32 to obtain intracellular values. This correction required the knowledge of both the amino acid concentration and enrichment in the interstitial fluid, and the proportion of intracellular and extracellular water in muscle. We have assumed that amino acid enrichment and concentrations in the interstitial fluid equaled blood values in the femoral vein (32). We have measured the intracellular and extracellular water volumes in the muscle tissue of three subjects using the chloride method (32). The ratio between intracellular and extracellular spaces averaged $0.16(\mathrm{SEM}=0.015)$. This value was in agreement with other laboratories (32) and was applied to all subjects.

Calculations. Muscle FSR in the basal period and during insulin infusion was calculated by dividing the increment in enrichment in the product, i.e., protein-bound $\mathrm{L}-\left[\right.$ ring $\left.{ }^{13} \mathrm{C}_{6}\right]$ phenylalanine tracer/tracee ratio, by the enrichment of the precursor, i.e., free intracellular $\mathrm{L}$-[ ring ${ }^{13} \mathrm{C}_{6}$ ] phenylalanine tracer/tracee ratio $(29,30)$. The use of the free intracellular phenylalanine enrichment as marker of the phenylalanyl

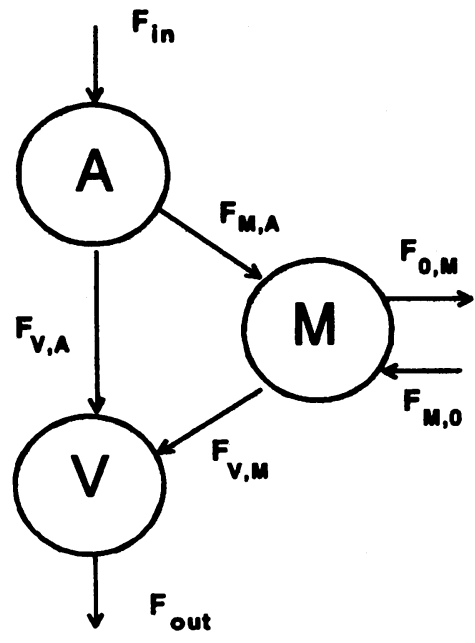

Figure 1. Three-compartmental model of leg muscle amino acid kinetics. Free amino acid pools in the femoral artery $(A)$, femoral vein $(V)$, and muscle $(M)$ are connected by arrows indicating the unidirectional amino acid flow between each compartment. Amino acids enter the leg via femoral artery $\left(F_{\text {in }}\right)$ and leave the leg via femoral vein $\left(F_{\text {out }}\right)$. $F_{V, A}$ indicates the direct amino acid flow from artery to vein without entering intracellular fluid; $F_{M, A}$ and $F_{V, M}$ refer to inward and outward amino acid transport from artery to muscle and from muscle to vein, respectively. $F_{M, 0}$ indicates the intracellular amino acid appearance from endogenous sources (i.e., proteolysis and novo synthesis, if any); $F_{0, M}$ is the rate of disappearance of intracellular amino acids (i.e., protein synthesis and other fates, if any).

total RNA enrichment in the skeletal muscle has been recently validated in vivo (37). Delta increments of protein-bound $\mathrm{L}$-[ring $\left.{ }^{13} \mathrm{C}_{6}\right]$ phenylalanine enrichment between the first and second biopsy (i.e., basal period $\left.\left[\triangle \mathrm{E}_{\mathrm{P}(\mathrm{BASAL} .)}\right]\right)$ and between the second and third biopsy (i.e., insulin infusion $\left[\Delta \mathrm{E}_{\mathrm{P}(\mathrm{INSU} \text { IN })}\right]$ ) were calculated from the values of isotope ratio ${ }^{13} \mathrm{C} /{ }^{12} \mathrm{C}$ in each biopsy:

$$
\begin{aligned}
& \Delta \mathrm{E}_{\mathrm{P} \text { (BASAL) }}=\left[{ }^{13} \mathrm{C} /{ }^{12} \mathrm{C}_{(2)}-{ }^{13} \mathrm{C} /{ }^{12} \mathrm{C}_{(1)}\right] \cdot 1.5 \\
& \Delta \mathrm{E}_{\mathrm{P} \text { (Insulin) }}=\left[{ }^{13} \mathrm{C} /{ }^{12} \mathrm{C}_{(3)}-{ }^{13} \mathrm{C} /{ }^{12} \mathrm{C}_{(2)}\right] \cdot 1.5
\end{aligned}
$$

where the subscripts 1,2 , and 3 denote values in the first, second, and third biopsy. Differences between ${ }^{13} \mathrm{C} /{ }^{12} \mathrm{C}$ isotope ratio in distinct biopsies were multiplied by the factor 1.5 to obtain the increment of tracer/tracee ratio of the protein-bound L- $\left[\right.$ ring $\left.{ }^{13} \mathrm{C}_{6}\right]$ phenylalanine from one biopsy to another. The factor 1.5 arises because in the L-[ring ${ }^{13} \mathrm{C}_{6}$ ] phenylalanine molecule, six of a total of nine carbon atoms are labeled. Then, FSRs were calculated as follows $(29,30)$ :

$$
\begin{aligned}
& \operatorname{FSR}_{\text {(BASAL) }}=\frac{\Delta E_{P_{(B A S A L)}}}{\left[\left(E_{M(1)}+E_{M(2)}\right) / 2\right] \cdot T_{(B A S A L)}} \cdot 60 \cdot 100 \\
& F_{\text {FSR }} \text { (INSULIN) } \\
& =\frac{\Delta E_{P_{(I N S U L I N)}}}{\left[\left(E_{M(2)}+E_{M(3)}\right) / 2\right] \cdot T_{(\text {INSULIN) }}} \cdot 60 \cdot 100
\end{aligned}
$$

FSR (BASAL) $_{\text {(nd FSR (INSULI) }}$ were the fractional synthetic rates of muscle protein in the periods between first and second biopsy (i.e., basal) and between second and third biopsy (i.e., insulin infusion), respectively. $E_{M(1)}, E_{M(2)}$, and $E_{M(3)}$ are the $L-\left[\right.$ ring $\left.{ }^{13} C_{6}\right]$ phenylalanine enrichments in the free muscle pool in the first, second, and third biopsy, respectively. Average values between $E_{M(1)}$ and $E_{M(2)}$ and between $E_{M(2)}$ and $E_{M(3)}$ values were used as precursor enrichments for muscle protein synthesis. $T_{\text {(BASAL) }}$ and $T_{\text {(INSULN) }}$ indicate time intervals ( $\mathrm{min}$ ) between first and second and second and third biopsy. The factors $60(\mathrm{~min} / \mathrm{h}$ ) and 100 are needed to express the FSR in percent per hour.

The kinetics of free amino acids in leg muscle have been described by the model shown in Fig. $1(28,29)$. Amino acids enter and leave the leg via femoral artery $\left(F_{\text {in }}\right)$ and femoral vein $\left(F_{\text {out }}\right)$, respectively. Free amino acid pools in arterial $(A)$ and venous (V) blood, and in muscle (M) are connected by arrows indicating the unidirectional amino acid flow between each compartment. $F_{M, A}$ and $F_{V, M}$ refer to the rates of net amino 
acid movement from artery to muscle and from muscle to femoral vein, i.e., inward and outward transmembrane transport, respectively. $F_{M, 0}$ for the essential amino acids phenylalanine, leucine, and lysine defines the rate of intracellular amino acid appearance from protein breakdown. In the case of alanine, $F_{M, 0}$ represents the sum of release from protein breakdown and de novo synthesis from pyruvate. Since phenylalanine and lysine are not oxidized in muscle (38), $\mathrm{F}_{0, \mathrm{M}}$ for these amino acids refers to the rate of utilization for protein synthesis. In the case of leucine, $F_{0, M}$ represents utilization for protein synthesis plus oxidation. Each kinetic parameter is defined as follows (see references 28 and 29 for the derivation of the equations):

$\mathrm{F}_{\text {in }}=\mathrm{C}_{\mathrm{A}} \cdot \mathrm{BF}$

$\mathrm{F}_{\text {out }}=\mathrm{C}_{\mathrm{V}} \cdot \mathrm{BF}$

$\mathrm{NB}=\left(\mathrm{C}_{\mathrm{A}}-\mathrm{C}_{\mathrm{V}}\right) \cdot \mathrm{BF}$

$F_{M, A}=\left\{\left[\left(E_{M}-E_{V}\right) /\left(E_{A}-E_{M}\right)\right] \cdot C_{V}+C_{A}\right\} \cdot B F$

$F_{V, M}=\left\{\left[\left(E_{M}-E_{V}\right) /\left(E_{A}-E_{M}\right)\right] \cdot C_{V}+C_{V}\right\} \cdot B F$

$\mathrm{F}_{\mathrm{V}, \mathrm{A}}=\mathrm{F}_{\mathrm{in}}-\mathrm{F}_{\mathrm{M}, \mathrm{A}}$

$\mathrm{F}_{\mathrm{M}, 0}=\mathrm{F}_{\mathrm{M}, \mathrm{A}} \cdot\left(\mathrm{E}_{\mathrm{A}} / \mathrm{E}_{\mathrm{M}}-1\right)$

$\mathrm{F}_{\mathrm{O}, \mathrm{M}}=\mathrm{F}_{\mathrm{M}, \mathrm{O}}+\mathrm{NB}$

where $C_{A}, C_{V}$ are free amino acid concentrations in the femoral artery and vein, respectively; $E_{A}, E_{V}$, and $E_{M}$ are amino acid enrichments in the femoral artery, femoral vein, and in muscle, respectively, and BF is leg blood flow.

The rate of inward amino acid transport can be influenced by the rate of amino acid delivery to muscle $\left(F_{i n}\right)$. This rate is dependent on the amino acid concentration in the artery as well as on the rate of blood flow. To account for the insulin-mediated variations in arterial amino acid concentrations and leg blood flow, the rates of inward amino acid transport $\left(F_{M, A}\right)$ were expressed in relation to regional amino acid flow $\left(F_{\text {in }}\right)$. Thus, the fraction $F_{M, A} / F_{i n}$ expresses the relative ability of muscle transporters to take up circulating amino acid. The remaining fraction of $F_{\text {in }}$, i.e., $F_{V, A} / F_{\text {in }}$, flows directly from the artery to the femoral vein without entering muscle cell. Computations of $\mathrm{F}_{\mathrm{M}, \mathrm{A}} / \mathrm{F}_{\text {in }}$ and $\mathrm{F}_{\mathrm{V}, \mathrm{A}} / \mathrm{F}_{\text {in }}$ are independent of leg blood flow.

This model assumes that muscle amino acid metabolism accounts for a large portion of the total leg metabolism. We have recently validated this assumption by showing that skin tissue accounts for a small portion of the total leg amino acid metabolism (39). Other leg tissues exhibit a very slow protein turnover (bone) (30) or account for too small a portion of total leg protein content (fat and bone marrow) (30) to be important determinants of leg protein metabolism.

Statistical analysis. Data were expressed as mean \pm SEM. Results before and after insulin infusion were compared with Student's paired $t$ test. A $P$ value of 0.05 or less was taken as indicating a significant difference.

\section{Results}

Plasma insulin concentration in the basal, postabsorptive state was $10 \pm 2 \mu \mathrm{U} / \mathrm{ml}$. After intraarterial infusion, insulin concentration increased to $77 \pm 9 \mu \mathrm{U} / \mathrm{ml}$ in the femoral vein $(P<0.01)$ and to $19 \pm 2 \mu \mathrm{U} / \mathrm{ml}$ in the arterialized wrist vein $(P<0.05)$. Plasma glucose concentration was $83 \pm 5 \mathrm{mg} / \mathrm{dl}$ in the basal
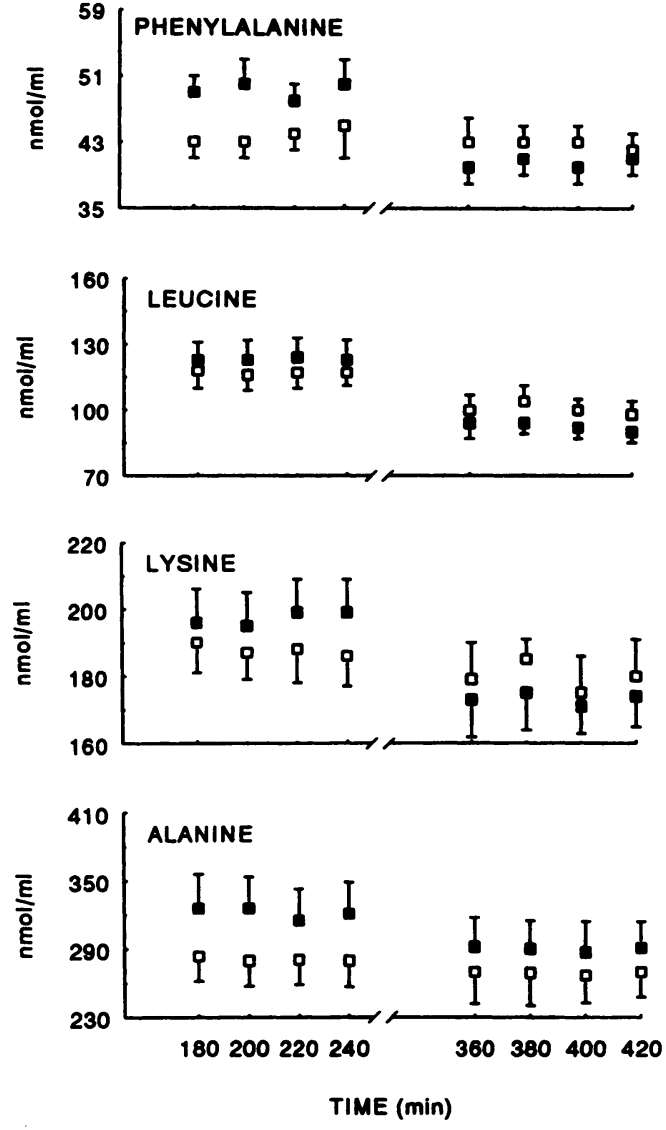

Figure 2. Whole-blood amino acid concentrations in the basal postabsorptive state, 180 to $240 \mathrm{~min}$, and during insulin infusion, 360 to 420 min. $\square$, femoral artery; $\mathbf{a}$, femoral vein.

state and was maintained approximately at the same level throughout the study by intravenous glucose infusion at a variable rate. In the last hour of the study, the glucose infusion rate was stable and averaged $1.67 \pm 0.56 \mathrm{mg} / \mathrm{min}$ per $\mathrm{kg}$. Leg blood flow increased $(P<0.05)$ after local insulin infusion from $3.16 \pm 0.39$ to $4.12 \pm 0.48 \mathrm{ml} / \mathrm{min}$ per $100 \mathrm{ml} \mathrm{leg}$.

Amino acid concentrations (Fig. 2) and enrichments (Fig. 3 ) in the femoral artery and vein were in steady state conditions in the last hour of the basal (i.e., between 180 and $240 \mathrm{~min}$ ) and insulin (i.e., between 360 and $420 \mathrm{~min}$ ) periods. In Tables I and II average values of free amino acid concentrations and enrichments in the femoral artery and vein and in muscle are reported. After local insulin infusion, arterial concentrations of phenylalanine, lysine, and alanine did not change significantly, whereas leucine slightly, but significantly, decreased. Intracellular concentrations of all essential amino acids decreased after insulin infusion, phenylalanine by $\sim 18 \%$, leucine by $\sim 35 \%$, and lysine by $\sim 28 \%$. As a consequence, the ratio between intracellular and arterial concentrations of all essential amino acids, expression of transmembrane gradient, decreased. During insulin infusion, there was a tendency of intracellular alanine concentration to increase, but this was not statistically significant. However, the increment of the cell/artery gradient for alanine concentration, was significant. After insulin infusion, the arterial enrichment of amino acids increased, indicating a decrease of the whole-body amino acid turnover. Intracellular 


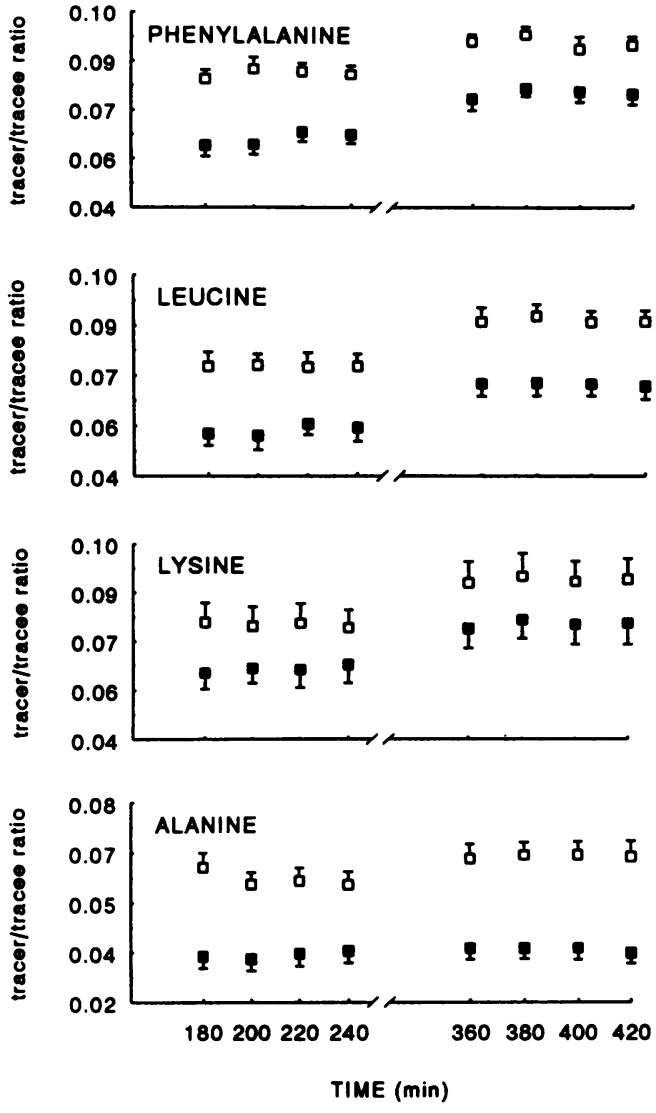

Figure 3. Whole-blood amino acid enrichments in the basal postabsorptive state, 180 to $240 \mathrm{~min}$, and during insulin infusion, 360 to $420 \mathrm{~min}$. ㅁ, femoral artery; $\mathbf{m}$, femoral vein.

enrichments and the ratios between intracellular and arterial enrichment did not change significantly for phenylalanine, leucine, and alanine, whereas all values for lysine increased. In

Table I. Concentrations of Free Amino Acids in Blood and Muscle, in the Basal State and during Local Hyperinsulinemia

\begin{tabular}{ccccc}
\hline & $\begin{array}{c}\text { Femoral } \\
\text { artery }\end{array}$ & $\begin{array}{c}\text { Femoral } \\
\text { vein }\end{array}$ & Muscle & $\begin{array}{c}\text { Muscle/artery } \\
\text { ratio }\end{array}$ \\
\hline $\begin{array}{l}\text { Phenylalanine } \\
\text { Basal }\end{array}$ & $44 \pm 2$ & $49 \pm 2$ & $124 \pm 16$ & $2.91 \pm 0.46$ \\
$\quad$ Insulin & $42 \pm 2$ & $41 \pm 2^{*}$ & $102 \pm 15^{*}$ & $2.47 \pm 0.41^{*}$ \\
Leucine & & & & \\
$\quad$ Basal & $117 \pm 7$ & $123 \pm 9$ & $216 \pm 9$ & $1.88 \pm 0.12$ \\
$\quad$ Insulin & $101 \pm 6^{*}$ & $93 \pm 5^{*}$ & $140 \pm 9^{*}$ & $1.40 \pm 0.05^{*}$ \\
Lysine & & & & \\
Basal & $188 \pm 9$ & $197 \pm 10$ & $965 \pm 117$ & $5.17 \pm 0.61$ \\
Insulin & $180 \pm 9$ & $174 \pm 10^{*}$ & $695 \pm 69^{*}$ & $3.86 \pm 0.29^{*}$ \\
Alanine & & & & \\
Basal & $281 \pm 22$ & $322 \pm 28$ & $2,215 \pm 202$ & $8.03 \pm 0.80$ \\
Insulin & $269 \pm 25$ & $290 \pm 25^{*}$ & $2,500 \pm 264$ & $9.53 \pm 0.98^{*}$ \\
& & & &
\end{tabular}

Concentrations are expressed as nanomoles per milliliter whole blood or intracellular water. Data are mean \pm SEM. $* P \leq 0.05$ insulin vs basal.
Table II. Enrichments of Free Amino Acids in Blood and Muscle, in the Basal State and during Local Hyperinsulinemia

\begin{tabular}{cllll}
\hline & Femoral artery & Femoral vein & Muscle & $\begin{array}{c}\text { Muscle/ } \\
\text { artery ratio }\end{array}$ \\
\hline $\begin{array}{c}\text { Phenylalanine* } \\
\text { Basal }\end{array}$ & $0.0816 \pm 0.0027$ & $0.0610 \pm 0.0029$ & $0.0462 \pm 0.0021$ & $0.57 \pm 0.01$ \\
$\begin{array}{c}\text { Insulin } \\
\text { Leucine }\end{array}$ & $0.0909 \pm 0.0024^{\ddagger}$ & $0.0753 \pm 0.0031^{\ddagger}$ & $0.0544 \pm 0.0041$ & $0.60 \pm 0.04$ \\
Basal & $0.0727 \pm 0.0037$ & $0.0537 \pm 0.0038$ & $0.0334 \pm 0.0034$ & $0.46 \pm 0.05$ \\
Insulin & $0.0866 \pm 0.0034^{\ddagger}$ & $0.0674 \pm 0.0037^{\ddagger}$ & $0.0429 \pm 0.0037$ & $0.50 \pm 0.04$ \\
$\begin{array}{c}\text { Lysine } \\
\text { Basal }\end{array}$ & $0.0750 \pm 0.0059$ & $0.0615 \pm 0.0052$ & $0.0258 \pm 0.0036$ & $0.34 \pm 0.03$ \\
Insulin & $0.0890 \pm 0.0064^{\ddagger}$ & $0.0752 \pm 0.0060^{\ddagger}$ & $0.0392 \pm 0.0041^{\ddagger}$ & $0.44 \pm 0.03^{\ddagger}$ \\
Alanine & & & & \\
Basal & $0.0570 \pm 0.0030$ & $0.0342 \pm 0.0023$ & $0.0135 \pm 0.0013$ & $0.23 \pm 0.01$ \\
Insulin & $0.0639 \pm 0.0041^{\ddagger}$ & $0.0359 \pm 0.0031$ & $0.0141 \pm 0.0014$ & $0.22 \pm 0.02$
\end{tabular}

Enrichments are expressed as tracer/tracee ratio. Data are mean \pm SEM. * Phenylalanine data are relative to the $\mathrm{L}-\left[\right.$ ring $-{ }^{13} \mathrm{C}_{6}$ ] phenylalanine tracer. ${ }^{\ddagger} P \leq 0.05$ insulin vs basal.

the four subjects that received simultaneous infusions of [2${ }^{15} \mathrm{~N}$ ] phenylalanine and $\mathrm{L}\left[\right.$ ring $-{ }^{13} \mathrm{C}_{6}$ ] phenylalanine at the same rates, the ratios between the enrichments of these two tracers were: femoral artery $0.99 \pm 0.02$ (basal) $0.96 \pm 0.02$ (insulin); femoral vein $0.95 \pm 0.01$ (basal) $1.02 \pm 0.02$ (insulin); muscle $0.93 \pm 0.10$ (basal) $1.07 \pm 0.12$ (insulin). These data demonstrated that the metabolism of these two tracers of phenylalanine is similar both in the skeletal muscle and at the whole body level.

Fig. 4 shows the effects of the intraarterial insulin infusion on the fractional synthesis rate of muscle protein. The increment (per hour) of the protein-bound $\mathrm{L}\left[\right.$ ring- $\left.{ }^{13} \mathrm{C}_{6}\right]$ phenylalanine enrichment $\left(\Delta \mathrm{E}_{\mathrm{P}}\right)$ was greater $(P<0.05)$ during insulin infusion $\left(1.15 \cdot 10^{-4} \pm 1.58 \cdot 10^{-5}\right)$ than in the basal period $(6.10 \cdot$ $\left.10^{-5} \pm 1.05 \cdot 10^{-5}\right)$. Enrichment of the free intracellular phenylalanine $\left(E_{M}\right)$ did not change significantly during the study (Table II). Consequently, the fractional synthesis rate of muscle protein was $\sim 65 \%$ higher $(P=0.02)$ during insulin infusion $(0.0677 \pm 0.0101 \% / \mathrm{h})$ than in the basal period $(0.0401$ $\pm 0.0072 \% / \mathrm{h}$ ) (Fig. 4)

Table III shows the insulin effects on the model-derived values of leg muscle amino acid kinetics. Phenylalanine kinetics was calculated using the $\mathrm{L}\left[\right.$ ring- $\left.{ }^{13} \mathrm{C}_{6}\right]$ phenylalanine tracer. The rate of leg arterial amino acid delivery from systemic circulation $\left(F_{\text {in }}\right)$ did not change significantly after insulin infusion. The net

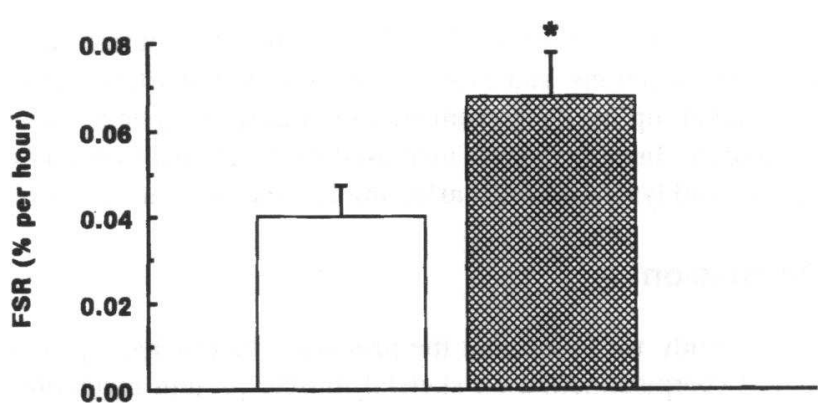

Figure 4. Insulin effects on FSR of muscle protein. ${ }^{*} P<0.05$ insulin vs basal (paired $t$ test). $\square$, basal; $\boldsymbol{\square}$, insulin. 
Table III. Insulin Effects on Parameters of Leg Muscle Amino Acid Kinetics

\begin{tabular}{|c|c|c|c|c|c|c|c|c|}
\hline & \multicolumn{2}{|c|}{ Phenylalanine* } & \multicolumn{2}{|c|}{ Leucine } & \multicolumn{2}{|c|}{ Lysine } & \multicolumn{2}{|c|}{ Alanine } \\
\hline & Basal & Insulin & Basal & Insulin & Basal & Insulin & Basal & Insulin \\
\hline$F_{\text {in }}$ & $142 \pm 25$ & $175 \pm 23$ & $379 \pm 63$ & $416 \pm 53$ & $598 \pm 80$ & $734 \pm 88$ & $883 \pm 127$ & $1,102 \pm 163$ \\
\hline$F_{\text {out }}$ & $158 \pm 25$ & $169 \pm 22$ & $401 \pm 72$ & $384 \pm 50$ & $626 \pm 86$ & $713 \pm 90$ & $1,005 \pm 142$ & $1,177 \pm 160$ \\
\hline NB & $-16 \pm 2$ & $+7 \pm 3^{\ddagger}$ & $-22 \pm 11$ & $+32 \pm 10^{\ddagger}$ & $-31 \pm 8$ & $+21 \pm 9^{\ddagger}$ & $-123 \pm 17$ & $-75 \pm 7$ \\
\hline $\mathrm{F}_{\mathrm{M}, \mathrm{A}}$ & $73 \pm 13$ & $81 \pm 11$ & $164 \pm 22$ & $200 \pm 25^{\ddagger}$ & $126 \pm 11$ & $221 \pm 30^{\ddagger}$ & $403 \pm 64$ & $595 \pm 106$ \\
\hline $\mathrm{F}_{\mathrm{V}, \mathrm{M}}$ & $90 \pm 13$ & $74 \pm 11$ & $186 \pm 27$ & $169 \pm 24$ & $157 \pm 8$ & $200 \pm 29$ & $525 \pm 79$ & $670 \pm 103$ \\
\hline $\mathrm{F}_{\mathrm{V}, \mathrm{A}}$ & $68 \pm 13$ & $95 \pm 16^{\ddagger}$ & $215 \pm 52$ & $216 \pm 36$ & $469 \pm 81$ & $513 \pm 69$ & $480 \pm 67$ & $507 \pm 74$ \\
\hline $\mathrm{F}_{\mathrm{M}, 0}$ & $56 \pm 9$ & $52 \pm 6$ & $188 \pm 21$ & $199 \pm 53$ & $250 \pm 20$ & $276 \pm 31$ & $1,323 \pm 200$ & $2,107 \pm 370^{5}$ \\
\hline $\mathrm{F}_{0, \mathrm{M}}$ & $40 \pm 8$ & $59 \pm 8^{\ddagger}$ & $166 \pm 21$ & $231 \pm 29$ & $219 \pm 21$ & $298 \pm 37^{8}$ & $1,200 \pm 186$ & $2,032 \pm 370^{8}$ \\
\hline
\end{tabular}

Units are nanomoles per minute per 100 milliliters leg. Data are mean \pm SEM. ${ }^{*}$ Phenylalanine kinetics was calculated using the $\mathrm{L}-\left[\right.$ ring $\left.-{ }^{13} \mathrm{C}_{6}\right] \mathrm{phenyl-}$ alanine enrichment data. ${ }^{\ddagger} P<0.05$ insulin vs basal; ${ }^{8} P<0.08$ insulin vs basal. $F_{\text {in }}$, amino acid flow into the leg from systemic circulation via femoral artery; $F_{\text {out }}$, amino acid flow from the leg via femoral vein; NB, net amino acid balance across the leg (negative numbers indicate net release); $F_{V, A}$, direct amino acid flow from artery to vein without entering intracellular fluid; $F_{M, A}$, inward amino acid transport from femoral artery into free muscle amino acid pool; $F_{\mathrm{V}, \mathrm{M}}$, outward amino acid transport from intracellular pool into femoral vein; $F_{\mathrm{M}, 0}$, intracellular amino acid appearance (i.e., proteolysis for phenylalanine, leucine, and lysine. Proteolysis plus de novo synthesis for alanine); $F_{0, M}$, intracellular amino acid utilization (i.e., protein synthesis for phenylalanine and lysine, protein synthesis plus other fates for leucine and alanine).

balance (NB) of phenylalanine and lysine, which at steady state reflects balance between protein synthesis and breakdown in leg muscle, shifted from a net output (negative values) in the postabsorptive state to a net uptake (positive value) during insulin infusion. Leucine balance also became positive after insulin. There was net release of alanine from muscle in both the basal state and during insulin infusion, although insulin tended to restrain alanine release. Local insulin infusion increased the inward transmembrane transport $\left(\mathrm{F}_{\mathrm{M}, \mathrm{A}}\right)$ of leucine, lysine, and alanine, whereas phenylalanine transport did not change significantly. The stimulatory effect of insulin on transport of each amino acid was quantitatively different. Lysine transport increased by $75 \pm 3 \%$, alanine by $45 \pm 3 \%$, and leucine only by $20 \pm 3 \%$. The rates of intracellular appearance $\left(F_{M, O}\right)$ from proteolysis of the essential amino acids phenylalanine, leucine, and lysine did not change after insulin infusion. In contrast, alanine appearance $\left(\mathrm{F}_{\mathrm{M}, \mathrm{O}}\right)$ tended to increase after insulin infusion, indicating an acceleration of the rate of alanine de novo synthesis. In agreement with data obtained with the direct incorporation technique, the model-derived value of intracellular phenylalanine disappearance $\left(\mathrm{F}_{\mathrm{O}, \mathrm{M}}\right)$ to protein synthesis significantly increased after insulin infusion. Also, lysine disappearance $\left(\mathrm{F}_{\mathrm{O}, \mathrm{M}}\right)$ to protein synthesis tended to increase after insulin infusion $(P<0.08)$. Fig. 5 shows the values of inward amino acid transport $\left(\mathrm{F}_{\mathrm{M}, \mathrm{A}}\right)$ normalized by the rate of arterial amino acid delivery $\left(F_{\text {in }}\right)$. This figure accounts for the insulinmediated variations of leg blood flow and of systemic amino acid concentrations, and expresses the fraction of arterial amino acids taken up by the transmembrane transport systems in the leg muscle. Insulin slightly increased the fractional transport of alanine and lysine, without affecting leucine and phenylalanine.

\section{Discussion}

In this study we found that the primary effect of local physiologic hyperinsulinemia on skeletal muscle protein metabolism was to increase the rate of protein synthesis, whereas the rate of protein breakdown did not change significantly. Transmembrane amino acid transport was not uniformly affected by insu- lin. The rate of alanine and lysine transport increased more than that of leucine, whereas transport of phenylalanine did not change significantly. Further, amino acid transport was not sufficiently accelerated to balance the increased utilization of intracellular amino acids for protein synthesis. As a consequence, the intramuscular concentrations of the essential amino acids decreased. These results indicate that insulin promotes net protein deposition in muscle by directly increasing the rate of protein synthesis. The regulation of transmembrane amino acid transport does not appear to be a primary mediator of the insulin anabolic action on muscle.

A number of studies, performed at the molecular level, have demonstrated insulin's ability to promote several steps of the process of protein synthesis in skeletal muscle (10). In contrast, when insulin effects on muscle protein synthesis have been evaluated in vivo, the results were less convincing, having depended on the method used and on the experimental conditions. A frequent complication is that systemic insulin infusion decreases plasma amino acid concentrations $(22,23)$ by acting at sites different than muscle (24). Thus, it is possible that, in some studies, a stimulatory effect on protein synthesis in vivo was obscured by the insulin-induced hypoaminoacidemia (24, 25 ). In fact, when amino acid concentrations were maintained

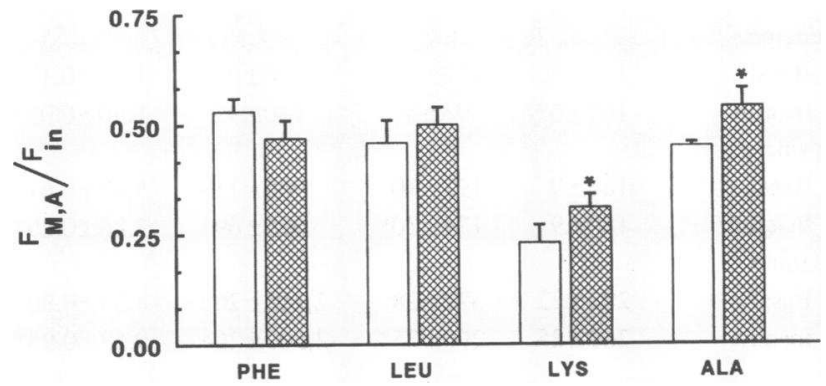

Figure 5. Insulin effects on rates of muscle amino acid transport in relation to arterial amino acid delivery $\left(\mathrm{F}_{\mathrm{M}, \mathrm{A}} / \mathrm{F}_{\mathrm{in}}\right) .{ }^{*} P<0.05$ insulin vs basal (paired $t$ test). $\square$, basal; $\square$, insulin. 
at levels higher than normal during systemic insulin infusion, insulin increased muscle protein synthesis (40). A further complication arose from the fact that muscle protein synthesis in humans was measured indirectly as the rate of disappearance of plasma amino acids across the leg or the forearm.

In this study we have assessed insulin effects on leg muscle protein synthesis by using two different techniques simultaneously. The results obtained with both methods were in agreement. Protein synthesis, measured either as the rate of amino acid (phenylalanine and lysine) disappearance from the intracellular pool or as the fractional synthesis rate of muscle protein, increased by $40-65 \%$ after insulin infusion. Further, a stimulation of muscle protein synthesis by insulin was also obtained if the rate of phenylalanine and lysine rate of disappearance ( $\mathrm{Rd}$ ) across the leg was calculated according to the traditional arteriovenous model $(26,27)$. Phenylalanine and lysine Rd increased significantly after insulin infusion, from $22 \pm 5$ to $35 \pm 5$ and from $73 \pm 7$ to $129 \pm 14 \mu \mathrm{mol} / \mathrm{min}$ per 100 $\mathrm{ml}$ leg, respectively.

The combination of the arteriovenous balance technique with the muscle biopsy allowed us to measure, directly, the rate of intracellular amino acid appearance from protein breakdown in muscle. We have used stable isotopic tracers of three different essential amino acids: phenylalanine, leucine, and lysine. The results obtained with all the three amino acids did not show any significant modification of protein breakdown by insulin infusion. This may represent a type 2 statistical error. However, the lack of a significant insulin effect on muscle protein breakdown we observed in vivo is consistent with expectations from in vitro findings (14). It has been shown that, during adequate amino acid supply, the most important degradative system in muscle is an ATP-independent system that requires the presence of a specialized protein, termed ubiquitin $(13,14,41)$. This system is not sensitive to insulin (14). Insulin apparently plays a role only in the regulation of the lysosome activity (14). These intracellular organelles are not involved in the myofibrillar protein degradation in normal conditions, but only in the presence of low insulin levels or decreased amino acid availability $(12-14)$. This was not the case in our study, where amino acid delivery to leg muscle $\left(F_{\text {in }}\right)$ did not decrease during local hyperinsulinemia.

In contrast to our findings, other investigators using different experimental designs, have shown that insulin decreased the rate of appearance $(\mathrm{Ra})$ of essential amino acids both across the forearm $(26,42)$ and the leg $(43)$, thus concluding that insulin suppressed muscle protein breakdown in vivo. In our study, amino acid $\mathrm{Ra}$ across the leg as calculated according to reference 26 , tended to decrease after insulin infusion for phenylalanine and leucine (from $39 \pm 6$ to $28 \pm 3(P=0.10)$ and from $96 \pm 11$ to $80 \pm 8(P=0.06) \mu \mathrm{mol} / \mathrm{min}$ per $100 \mathrm{ml}$, respectively). For lysine, however, there was no change (from $104 \pm 5$ to $108 \pm 11 \mu \mathrm{mol} / \mathrm{min}$ per $100 \mathrm{ml} \mathrm{leg}$ ). These data, however, do not necessarily reflect a decreased rate of protein breakdown. Amino acids appearing intracellularly from protein breakdown can either be transported out of the cell $\left(\mathrm{F}_{\mathrm{V}, \mathrm{M}}\right)$ and appear into the bloodstream, or be reutilized for protein synthesis (or oxidation in the case of leucine) $\left(\mathrm{F}_{\mathrm{O}, \mathrm{M}}\right)$. Thus, in our study, the apparent discrepancies between the traditional calculation of plasma amino acid $\mathrm{Ra}$ and the rates of intracellular amino acid appearance from protein breakdown calculated by our model, can be explained by the effect of insulin on the relative rates of protein synthesis and outward transport (the ratio $\left.\mathrm{F}_{\mathrm{V}, \mathrm{M}} / \mathrm{F}_{\mathrm{O}, \mathrm{M}}\right)$. This ratio decreased after insulin infusion for phenylalanine (from $2.49 \pm 0.23$ to $1.31 \pm 0.22$ ) and leucine (from $1.23 \pm 0.24$ to $0.82 \pm 0.23$ ) indicating that relatively more phenylalanine appearing from protein breakdown was directed to protein synthesis than to outward transport. For lysine, however, no change of the ratio $\mathrm{F}_{\mathrm{V}, \mathrm{M}} / \mathrm{F}_{\mathrm{O}, \mathrm{M}}$ was observed (from $0.76 \pm 0.10$ to $0.70 \pm 0.12$ ). These results show that the traditional measurement of amino acid $\mathrm{Ra}$ in plasma is a poor index of protein breakdown, since they are strongly influenced by the relative rates of outward transport and protein synthesis (or oxidation in the case of leucine). In addition, it has been recently shown that insulin infusion decreased phenylalanine and tyrosine $\mathrm{Ra}$ across the arm without affecting 3-methylhistidine release from muscle, an index of myofibrillar protein degradation that cannot be reutilized for protein synthesis (44). These results may be interpreted as a selective insulin effect on the nonmyofibrillar protein degradation, or, alternatively, they may further demonstrate the unreliability of the amino acid $\mathrm{Ra}$ in plasma as markers of muscle protein breakdown.

In our study, after insulin infusion, inward transmembrane transport of alanine, lysine, and leucine significantly increased, whereas transport of phenylalanine did not change. Acceleration of alanine and lysine transport (approximately $+48 \%$ and $+75 \%$, respectively) was more pronounced than that of leucine (approximately $+22 \%$ ). The same results were obtained also after normalization of inward transport per unit of amino acid concentration in the artery. This normalization accounts for the slight changes of systemic amino acid concentrations after insulin. The insulin effect on alanine transport was expected on the basis of a large number of studies. Alanine is a major substrate of system A, a sodium-dependent system that maintains steep transmembrane gradients of amino acid concentrations. This system has been shown to be regulated by insulin both in vitro and in vivo (15-17, 19-21). Lysine is a cationic amino acid that is transported by the sodium independent system $\mathrm{y}^{+}$. Its activity is sodium independent, but is strongly influenced by the electrochemical potential of cell membrane $(20,45)$. Insulin has been shown to induce hyperpolarization in the skeletal muscle cells by directly activating the $\mathrm{Na}^{+}-\mathrm{K}^{+}$-ATPase pump (46). Thus, acceleration of lysine transport may be secondary to the primary insulin effect on the electrochemical transmembrane gradient. The insulin effect on leucine transport is unexpected on the basis of in vitro studies. The branched-chain (leucine, valine, and isoleucine) and the aromatic (phenylalanine and tyrosine) amino acids are preferably transported through system $\mathrm{L}(15-17,19,20)$. This sodium-independent system is unable to generate high transmembrane gradients for its substrates (15$17,19,20)$. It has been shown that the kinetic characteristics of system $L$ are not influenced by insulin $(15-17,19,20)$. However, the postinsulin increase in leg blood flow may increase local amino acid delivery to muscle and, secondarily, amino acid transport. To exclude the effect of variations of blood flow, we have normalized inward amino acid transport per unit amino acid delivery. This figure is independent of blood flow and arterial amino acid concentration. After this normalization (Fig. 5), we found that the fractional transport of alanine and lysine was still slightly increased after insulin by $\sim 20$ and $\sim 35 \%$, respectively, whereas transport of leucine and phenylalanine did not change. Thus, it is likely that the insulin action on leucine transport was not direct but mediated by an increase in blood flow.

After insulin infusion, the intracellular alanine production 
$\left(F_{M, O}\right)$ tended to increase in muscle (Table III). This change was completely accounted for by an acceleration of alanine de novo synthesis from pyruvate, because the rate of amino acid appearance from protein breakdown did not increase after insulin (Table III). In a variety of physiological circumstances, alanine formation is a function of the availability of pyruvate rather than of the rate of protein breakdown $(47,48)$. Thus, an increase of alanine synthesis would be expected in our study because of the insulin-mediated increase of glucose uptake and intracellular production of pyruvate in muscle. Despite the increased intracellular alanine formation, alanine release from muscle did not increase (Table III). This is explained by the fact that the rate of inward alanine transport also increased. As a consequence, the intracellular concentration of alanine increased after insulin infusion (Table I).

The values of intracellular amino acid enrichments used in the calculations have been obtained from the values relative to the total tissue water corrected for the water distribution between the intracellular and extracellular spaces $(29,32)$. We have assumed that amino acid enrichments and concentrations in the femoral vein were representative of the values in the interstitial fluid. However, the true values of amino acid enrichment and concentrations in the interstitial fluids are not known, lying between the values in the femoral artery and those relative to the total tissue water, i.e., the uncorrected values of tissue amino acid enrichments and concentrations. When the arterial values are used in the correction of the biopsy data there is $a-3 \%$ increase of the values of FSR of muscle protein both before and after insulin infusion. Values of $F_{O, M}$ and $F_{M, O}$ also increased between 1 and $6 \%$, depending on the different amino acids. Values of $F_{M, A}$ and $F_{V, M}$ decreased between 1 and 5\% depending on the different amino acids. When the uncorrected values of muscle amino acid enrichment are used in the calculations there is a $\sim 2 \%$ decrease of the values of FSR of muscle protein both before and after insulin infusion. Values of $F_{O, M}$ and $F_{M, O}$ also decreased between 1 and $6 \%$ depending on the different amino acids. Values of $F_{M, A}$ and $F_{V, M}$ increased between 1 and $5 \%$ depending on the different amino acids. These results show that the assumptions relative to the interstitial fluid have only a minor effect on the calculation of the kinetic parameters and do not change the significance of our data. In addition, an insulin-mediated increase of the ratio between extracellular and intracellular volumes in muscle would result in an overestimation of the true intracellular enrichment, meaning that the increase in protein synthesis would be even greater than we calculated.

In agreement with other previous observations (19), our data show that the transmembrane amino acid transport is not likely an important mechanism for the insulin regulation of protein metabolism. In our study, local insulin infusion decreased the intracellular concentrations of the free essential amino acids, despite the maintenance of nearly normal arterial delivery of amino acids $\left(F_{i n}\right)$. This indicates that the insulinmediated stimulation of protein synthesis was not matched by a similar acceleration of the rate of inward amino acid transport $\left(F_{M, A}\right)$. In this circumstance, the anabolic effect of insulin on muscle may have become self-limited because of an intracellular depletion of precursor amino acids for protein synthesis, unless amino acid transport is independently stimulated by other factors, i.e., amino acid administration.

\section{Acknowledgments}

The authors acknowledge the technical assistance of Guy L. Jones, Dorothy Hogg, Paola Lasko, and Yun-Xia Lin, and the assistance of the nursing staff of the Clinical Research Center of The University of Texas Medical Branch at Galveston, Texas.

This study was supported by National Institutes of Health grants DK 38010 and DK 33952, General Clinical Research Center grant 00074, and grant 15849 from the Shriners Hospital.

\section{References}

1. Kimbal, S. R., K. E. Flaim, D. E. Peavy, and L. S. Jefferson. 1989. Protein metabolism. In Diabetes Mellitus, Theory and Practice. M. Ellemberg, and M. Rifkin, editors. Elsevier Science Publishing Co., Inc., New York/Amsterdam/ London. 41-50.

2. Biolo, G., and R. R. Wolfe. 1993. Insulin action on protein metabolism. In Insulin Resistance and Disease. Vol. 7: Clinical Endocrinology and Metabolism. E. Ferrannini, editor. Bailliere Tindall Ltd. London. 989-1005.

3. Manchester, K. L., and F. G. Young. 1958. The effect of insulin on the incorporation of amino acid into protein of normal rat diaphragm in vitro. Biochem. J. 70:353-358.

4. Jefferson, L. S., J. O. Koehler, and H. E. Morgan. 1972. Effect of insulin on protein synthesis in skeletal muscle of an isolated perfused preparation of rat hemicorpus. Proc. Natl. Acad. Sci. USA. 69:816-820.

5. Pain, W. M., and P. J. Garlic. 1974. Effect of streptozotocin diabetes and insulin treatment on the rate of protein synthesis in tissues of the rat in vivo. $J$. Biol. Chem. 249:4510-4514.

6. Fulks, R., J. B. Li, and A. L. Goldberg. 1975. Effect of insulin, glucose and amino acids on protein turnover in rat diaphragm. J. Biol. Chem. 250:290298.

7. Airhart, J., J. A. Arnold, W. S. Stirewalt, and R. B. Low. 1982. Insulin stimulation of protein synthesis in cultured skeletal and cardiac muscle cells. Am. J. Physiol. 243:C81-C86.

8. Pain, W. M., E. C. Albertse, and P. J. Garlick. 1983. Protein metabolism in skeletal muscle, diaphragm and heart of diabetic rats. Am. J. Physiol. 245 (Endocrinol. Metab. 6):E604-E610.

9. Garlick, P. J., and I. Grant. 1988. Amino acid infusion increases the sensitivity of muscle protein synthesis in vivo to insulin. Biochem. J. 254:579-584.

10. Kimball, S. R., and L. S. Jefferson. 1988. Cellular mechanisms involved in the action of insulin on protein synthesis. Diabetes Metab. Rev. 4:773-787.

11. Mortimore, G. A., W. F. Ward, and C. M. Schworer. 1978. Lysosomal processing of intracellular proteins in rat liver and its general regulation by amino acids and insulin. In Protein Turnover and Lysosome Function. H. L. Segal and D. J. Dole, editors. Academic Press, New York. 67-87.

12. Lowell, B. B., N. B. Ruderman, and M. N. Goodman. 1986. Evidence that lysosomes are not involved in the degradation of myofibrillar proteins in rat skeletal muscle. Biochem. J. 234:237-240.

13. Furuno, K., and A. L. Goldberg. 1986. The activation of protein degradation in muscle by $\mathrm{Ca}^{++}$or muscle injury does not involve a lysosomal mechanism. Biochem. J. 237:859-864.

14. Kettelhut, I. C., S. S. Wing, and A. L. Goldberg. 1988. Endocrine regulation of protein breakdown in skeletal muscle. Diabetes Metab. Rev. 4:751-772.

15. Christensen, H. N. 1990. Role of amino acid transport and countertransport in nutrition and metabolism. Physiol. Rev. 70:43-77.

16. Guidotti, G. G., A. F. Borghetti, and G. C. Gazzola. 1978. The regulation of amino acid transport in animal cells. Biochim. Biophys. Acta. 515:329-366.

17. Shotwell, M. A., M. S. Kilberg, and D. L. Oxender. 1983. The regulation of neutral amino acid transport in mammalian cells. Biochim. Biophys. Acta. 737:267-284.

18. Hundal, H. S., M. J. Rennie, and P. W. Watt. 1987. Characteristics of L glutamine transport in perfused rat skeletal muscle. J. Physiol. (Lond.). 393:283305.

19. Hundal, H. S., M. J. Rennie, and P. W. Watt. 1989. Characteristics of acid, basic and neutral amino acid transport in the perfused rat hindlimb. $J$. Physiol. (Lond.). 408:93-114.

20. Guidotti, G. G., and G. C. Gazzola. 1992. Amino acid transporters: systematic approach and principles of controls. In Mammalian Amino Acid Transport. M. S. Kilberg and D. Haüssinger, editors. Plenum Publishing Corp., New York, 3-29.

21. Bonadonna, R. C., M. P. Saccomani, C. Cobelli, and R. A. DeFronzo. 1993. Effect of insulin on system A amino acid transport in human skeletal muscle. J. Clin. Invest. 91:514-521.

22. Fukagawa, N. K., K. L. Minaker, V. R. Young, and J. W. Rowe. 1986. Insulin dose dependent reductions in plasma amino acids in man. Am. J. Physiol. 250:E13-E17.

23. Tessari, P., R. Trevisan, S. Inchiostro, S. Vigili de Kreutzenberg, G. Biolo, E. Duner, A. Tiengo, and G. Crepaldi. 1986. Dose-response curves of the effects of insulin on leucine kinetics in man. Am. J. Physiol. 251:E334-E343.

24. Tessari, P., S. Inchiostro, G. Biolo, E. Vincenti, and L. Sabadin. 1991. Effects of acute systemic hyperinsulinemia on forearm muscle proteolysis in healthy man. J. Clin. Invest. 88:27-33. 
25. Arfviddsson, B., H. Zachrisson, A. C. Möller-Loswick, A. Hyltander, R. Sandström, and K. Lundholm. 1991. Effect of systemic hyperinsulinemia on amino acid flux across human legs in postabsorptive state. Am. J. Physiol. 260:E46-E52.

26. Gelfand, R. A., and E. J. Barrett. 1987. Effect of physiologic hyperinsulinemia on skeletal muscle protein synthesis and breakdown in man. J. Clin. Invest. 80:1-6.

27. Gelfand, R. A., M. G. Glickman, P. Castellino, R. J. Louard, and R. A. DeFronzo. 1988. Measurement of $\mathrm{L}-\left[1-{ }^{14} \mathrm{C}\right]$ leucine kinetics in splanchnic and leg tissues in humans. Diabetes. 37:1365-1372.

28. Biolo, G., D. Chinkes, X. J. Zhang, and R. R. Wolfe. 1992. A new model to determine in vivo the relationship between amino acid transmembrane transport and protein kinetics in muscle. J. Parenter. Enteral. Nutr. 16:305-315.

29. Biolo, G., R. Y. D. Fleming, S. P. Maggi, and R. R. Wolfe. 1994. Transmembrane transport and intracellular kinetics of amino acids in human skeletal muscle. Am. J. Physiol. (Endocrinol. Metab.). In press.

30. Waterlow, J. C., P. J. Garlic, and D. J. Millward. 1978. Protein Turnover in Mammalian Tissues and in the Whole Body. North-Holland, Amsterdam/New York/Oxford. 339-377.

31. Katch, V., and A. Weltman. 1975. Predictability of body segment volumes in living subjects. Hum. Biol. 47:203-218.

32. Bergström, J., F. Fürst, L. O. Norée, and E. Vinnars. 1974. Intracellular free amino acid concentration in human muscle tissue. J. Appl. Physiol. 36:693697.

33. Jorfeldt, L., and J. Waren. 1971. Leg blood flow during exercise in man Clin. Sci. (Lond.). 41:459-473.

34. Jorfeldt, L., and A. Juhlin-Dannfelt. 1978. The influence of ethanol on splanchnic and skeletal muscle metabolism in man. Metab. Clin. Exp. 27:97106.

35. Wolfe, R. R. 1992. Radioactive and stable isotope tracers in biomedicine. In Principles and Practice of Kinetics Analysis. Wiley-Liss, New York. 417-419.

36. Carraro, F., C. A. Stuart, W. H. Hartl, J. Rosemblatt, and R. R. Wolfe 1990. Effect of exercise and recovery on muscle protein synthesis in human subjects. Am. J. Physiol. 258 (Endocrinol. Metab. 21):E420-E476.

37. Baumann, P. Q., W. S. Stirewalt, B. D. O'Rourke, and K. S. Nair. 1994 Precursor pools of protein synthesis: a stable isotope study in a swine model. Am. J. Physiol. 267:E203-E209.
38. Miller, L. L. 1962. The role of the liver and the non-hepatic tissues in the regulation of free amino acid levels in the blood. In Amino Acid Pools. J. T. Holden, editor. Elsevier Science Publishers B. V., Amsterdam. 708-722.

39. Biolo, G., A. Gastaldelli, X. J. Zhang, and R. R. Wolfe. 1994. Protein synthesis and breakdown in skin and muscle: a leg model of amino acid kinetics. Am. J. Physiol. 267:E467-E474.

40. Bennett, W. M., A. A. Connacher, C. M. Scringeour, R. T. Jung, and M. J. Rennie. 1990. Euglycemic hyperinsulinemia augments amino acid uptake by human leg tissues during hyperaminoacidemia. Am. J. Physiol. 259:E185E194.

41. Fagan, J. M., L. Waxman, and A. L. Goldberg. 1987. Skeletal muscle and liver contain a soluble ATP+ubiquitin-dependent proteolytic system. Biochem. J. 243:335-343.

42. Heslin, M. J., E. Newman, R. F. Wolf, P. W. T. Pisters, and M. F. Brennan 1992. Effect of hyperinsulinemia on whole body and skeletal muscle leucine carbon kinetics in humans. 1992. Am. J. Physiol. 262:E911-E918.

43. Denne, S. C., E. A. Liechty, Y. M. Liu, G. Brechtel, and A. D. Baron. 1991. Proteolysis in skeletal muscle and whole body in response to euglycemic hyperinsulinemia in normal adults. Am. J. Physiol. 261:E809-E814.

44. Möller-Loswick, A. C., H. Zachrisson, A. Hyltander, U. Körner, D. E. Matthews, and K. Lundholm. 1994. Insulin selectively attenuates breakdown of nonmyofibrillar proteins in peripheral tissues of normal men. Am. J. Physiol. 266:E645-E652.

45. Bussolati, O., P. C. Laris, F. A. Nucci, V. Dall'Asta, N. Longo, G. G. Guidotti, and G. C. Gazzola. 1987. Dependence of L-arginine accumulation on membrane potential in cultured human fibroblasts. Am. J. Physiol. 253:C391C397.

46. Iannaccone, S. T., K. X. Li, N. Sperelakis, and D. A. Lathrop. 1989 Insulin-induced hyperpolarization in mammalian skeletal muscle. Am. J. Physiol. 256:C368-C374.

47. Royle, G. T., J. A. Molnar, M. H. Wolfe, R. R. Wolfe, and J. F. Burke 1982. Urea, glucose, and alanine kinetics in man: effects of glucose infusion. Clin. Sci. (Lond.). 62:553-556.

48. Jahoor, F., D. N. Herndon, and R. R. Wolfe. 1986. Role of insulin and glucagon in the response of glucose and alanine kinetics in burn-injured patients. J. Clin. Invest. 78:807-814. 